Article

\title{
Performance Evaluation of Pilot-scale Hybrid Anaerobic Baffled Reactor (HABR) to Process Dyeing Wastewater Based on Grey Relational Analysis
}

\author{
Zhixin Qi ${ }^{1, *}$, Guoli Xiang ${ }^{2}$ and Deqi Xiong ${ }^{1, *}$ \\ 1 College of Environmental Sciences and Engineering, Dalian Maritime University, Dalian 116026, China \\ 2 Jiuquan Environmental Monitoring Station, Jiuquan 735000, China; xiangguoli15@126.com \\ * $\quad$ Correspondence: qizhixin@dlmu.edu.cn (Z.Q.); xiongdq@dlmu.edu.cn (D.X.); Tel.: +86-411-84729615 (D.X.)
}

Received: 23 March 2019; Accepted: 9 May 2019; Published: 14 May 2019

\begin{abstract}
A pilot-scale six-compartment hybrid anaerobic baffled reactor (HABR) with effective volume of $18 \mathrm{~m}^{3}$ was used to treat dyeing wastewater. The HABR system was able to treat the wastewater efficiently after $\mathrm{FeSO}_{4}$ pretreatment, as indicated by removal efficiencies of $33.7 \%$ for chemical oxygen demand (COD), 39.9\% for suspended solid (SS), and $22.5 \%$ for sulfate $\left(\mathrm{SO}_{4}{ }^{2-}\right)$ during steadily operational period. Gas chromatography-mass spectrometry (GC-MS) showed that the concentrations of alkanes, amides, organic acids, ketones, phenols, and esters were much lower in the effluent than those in the influent; many high-molecular-weight compounds such as cyclanes, quinolines, and phenols were successfully transformed to low-molecular-weight ones. As illustrated from the results of generalized grey relational analysis (GGRA), COD removal efficiency was more closely associated with flow rate, organic loading rate (OLR), water temperature, and influent SS among the whole selected possible factors. Based on the overall treating effectiveness and the GGRA study, the optimized operation strategy of the dyeing wastewater treatment by HABR was obtained as the hydraulic retention time (HRT) of $12 \mathrm{~h}$ for steady-state operation with an up-flow velocity of $1.7 \mathrm{~m} / \mathrm{h}$ as well as OLR of $1.5-2.0 \mathrm{~kg} \mathrm{COD} /\left(\mathrm{m}^{3} \cdot \mathrm{d}\right)$.
\end{abstract}

Keywords: dyeing wastewater; hybrid anaerobic baffled reactor; grey relational analysis; pilot-scale; removal efficiency

\section{Introduction}

Around 50,000 metric tons of synthetic dyes are discharged with wastewater worldwide every year [1,2]. Generally, dyeing wastewater is characterized by high $\mathrm{pH}$, deep color, strong toxicity, various components, and wide range of water quality and amount variation [3,4]. Dyeing wastewater is commonly treated by economic and effective biochemical methods. However, the recalcitrant nature of azo dyes, together with their toxicity to microorganisms, makes aerobic treatment difficult to meet the discharge criterion. In anaerobic treatment, microbial hydrolyzation and acidification by microorganisms may convert recalcitrant organic matter in dyeing wastewater to biologically degradable ones, improve biodegradability of the wastewater, and remove a portion of organisms to create an advantageous nutritional condition for the subsequent aerobic treatment in dyeing wastewater [5-7].

A few types of anaerobic reactors, such as up-flow anaerobic sludge blanket (UASB) [8-11], expanded granular sludge bed (EGSB) [12], anaerobic baffled reactor (ABR) [13,14], strengthened circulation anaerobic reactor (SCAR) [15], anaerobic membrane bioreactors (An MBRs) [16], anaerobic sequential batch reactor (ASBR) [17], and anaerobic side-stream reactor (ASSR) [18], have been employed to process dyeing wastewater. Recent studies on dyeing wastewater treatment by pilot-scale 
anaerobic reactors are summarized in Table 1, which have achieved chemical oxygen demand (COD) removal rate between 10 and $45.8 \%$ with organic loading rate (OLR) at $0.53-7.4 \mathrm{~kg} \mathrm{COD} /\left(\mathrm{m}^{3} \cdot \mathrm{h}\right)$. Among these technologies, ABR takes advantage of baffle-board structure to form several separate compartments inside the reactor, the flow regime in which is mainly plug flow. ABR also forms multilevel and multiphase anaerobic environment, and has fine buffer capability resistant to shock loads and adaptability to influent toxicants [19]. It uses up-and-down water stream to stir anaerobic sludge to mix with wastewater; its structure and flow regime make a certain microorganism community cultivated in each of its compartments, which acclimates its inflowing wastewater quality and environmental condition. Thus, nicer biological population distribution will be formed to improve treatment efficiency and operation stability due to the unique structure and flow regime of the reactor [20,21]. However, solids loss is a disadvantage of ABR, especially at high hydraulic loads [22].

Table 1. Summarization of recent studies on dyeing wastewater treatment by pilot-scale anaerobic reactors.

\begin{tabular}{|c|c|c|c|c|c|c|}
\hline $\begin{array}{l}\text { Treatment } \\
\text { Technology }\end{array}$ & $\begin{array}{l}\text { Working } \\
\text { Volume } \\
\left(\mathrm{m}^{3}\right)\end{array}$ & $\begin{array}{c}\text { Hydraulic } \\
\text { Retention } \\
\text { Time, h (HRT) }\end{array}$ & $\begin{array}{l}\text { Up-flow } \\
\text { Velocity } \\
(\mathrm{m} / \mathrm{h})\end{array}$ & $\begin{array}{c}\text { Organic } \\
\text { Loading Rate } \\
(\mathrm{OLR}), \mathrm{kg} \\
\left.\mathrm{COD} /\left(\mathrm{m}^{3} \mathrm{~h}\right)\right)\end{array}$ & $\begin{array}{c}\text { Chemical Oxygen } \\
\text { Demand (COD) } \\
\text { Removal Rate } \\
(\%)\end{array}$ & Reference \\
\hline ABR & 6 & $12-13$ & $1.15-1.25$ & $0.8-0.96$ & 45.8 & [13] \\
\hline EGSB & 0.78 & 15 & 0.18 & 2.1 & 35.1 & [12] \\
\hline UASB & 0.78 & 15 & 0.18 & 2.1 & 35 & [8] \\
\hline SCAR & 27 & 13.5 & 1.1 & $2.5-7.4$ & $\begin{array}{c}34.1 \\
\text { (no reflux) }\end{array}$ & [15] \\
\hline UASB & 5 & 18 & 0.25 & $0.53-1.9$ & $10-19$ & [9] \\
\hline
\end{tabular}

Up to now, most reported studies are laboratory scale, and limited information is available on full or pilot-scale ABR implementations [23]. In this study, a pilot-scale HABR was built to treat dyeing wastewater after $\mathrm{FeSO}_{4}$ coagulation pretreatment. In order to create cross-flow conditions inside the reactor to maintain high biomass concentration in this study, cross-flow packing was developed and utilized in each compartment of the ABR to form a hybrid anaerobic baffled reactor (HABR). The improvement of the structure led to the adherence of the microorganisms on the packing to form biofilms, and further increased the microbial richness and diversity [18,24].

Recently, a future research direction from a review conducted on the state-of-the-art anaerobic biological technologies for processing dyeing wastewater has been clearly pointed out, which is to determine the boundary conditions for high-performance operations of anaerobic reactors [16]. Researchers have employed a few methods to evaluate the performance of the anaerobic reactor in processing wastewater, including tests of organic and iron contents in the wastewater based on gas chromatography mass spectrometry and spectrophotometer [12,25], analysis of microbial communities by fluorescence in situ hybridization, polymerase chain reaction and denaturing gradient gel electrophoresis [26,27], and biological toxicity tests [13]. However, limited literature has been found on the reactor performance evaluation based on mathematical diagnostic tools [28]. The main purpose of this study is to evaluate the performance of the improved pilot scale anaerobic reactor in processing dyeing wastewater based on the grey relational analysis. In order to supply reference for technical design and operational parameter optimization of the plant's reconstructive engineering, the change of water quality, and the degradation of organic pollutants, as well as the influencing factors of the COD removal based on the GGRA (generalized grey relational analysis) are discussed.

\section{Materials and Methods}

\subsection{Designed Inflow Wastewater Quality}

The designed wastewater treatment capability of the first project in a wastewater treatment plant is $300,000 \mathrm{~m}^{3} / \mathrm{d}$, in which the wastewater was composed of $90 \%$ dyeing wastewater, $8 \%$ municipal sewage, and $2 \%$ other industrial wastewater. The main pollutants came from the alkali-decomposition 
processes of dyeing, printing, potch, and other processes. In this pilot scale study, the wastewater was pretreated by $\mathrm{FeSO}_{4}$ coagulation, and then sedimented in the wastewater treatment plant. The effluent from the sedimentation tank was then treated in the HABR. The wastewater quality from the effluent of the sedimentation tank was shown in Table 2.

Table 2. Wastewater quality.

\begin{tabular}{cccccccc}
\hline Index & $\begin{array}{c}\text { Chemical } \\
\text { oxygen demand } \\
\text { (COD) }\end{array}$ & $\mathbf{p H}$ & $\begin{array}{c}\text { Total } \\
\text { Nitrogen }\end{array}$ & $\begin{array}{c}\text { Total } \\
\text { Phosphorus }\end{array}$ & Sulfates & $\begin{array}{c}\text { Suspended } \\
\text { solid (SS) }\end{array}$ & Color \\
\hline Unit & $\mathrm{mg} / \mathrm{L}$ & - & $\mathrm{mg} / \mathrm{L}$ & $\mathrm{mg} / \mathrm{L}$ & $\mathrm{mg} / \mathrm{L}$ & $\mathrm{mg} / \mathrm{L}$ & times \\
Value & $700-1300$ & $9-11$ & $40-45$ & $0.5-3$ & $800-1200$ & $150-350$ & $200-300$ \\
\hline
\end{tabular}

\subsection{System Description}

In this study, the technological system flow is shown in Figure 1. The HABR system was made up of six compartments. Each compartment had an open upside for wastewater sampling and a tap at the downside for sludge sampling. A baffle was set in each compartment to make the inflow first mix downwards with the fluid at a relatively high speed. At the bottom of the baffle, there was a $30^{\circ}$ guide baffle to make sure that wastewater was transferred to the downside center of the room bottom in order to mix with the sludge adequately in the reactor room [29]. Then the wastewater experienced an upward flow before entering the next compartment. The cross-flow packing largely increased the chance of contact between organic pollutants and biofilms. Each compartment of the HABR had a cubic size of $1.5 \mathrm{~m} \times 0.6 \mathrm{~m} \times 3.6 \mathrm{~m}$ (length $\times$ width $\times$ height) and the effective working volume of the whole reactor was $18.0 \mathrm{~m}^{3}$ with the final flow rate of $1.5 \mathrm{~m}^{3} / \mathrm{h}$.

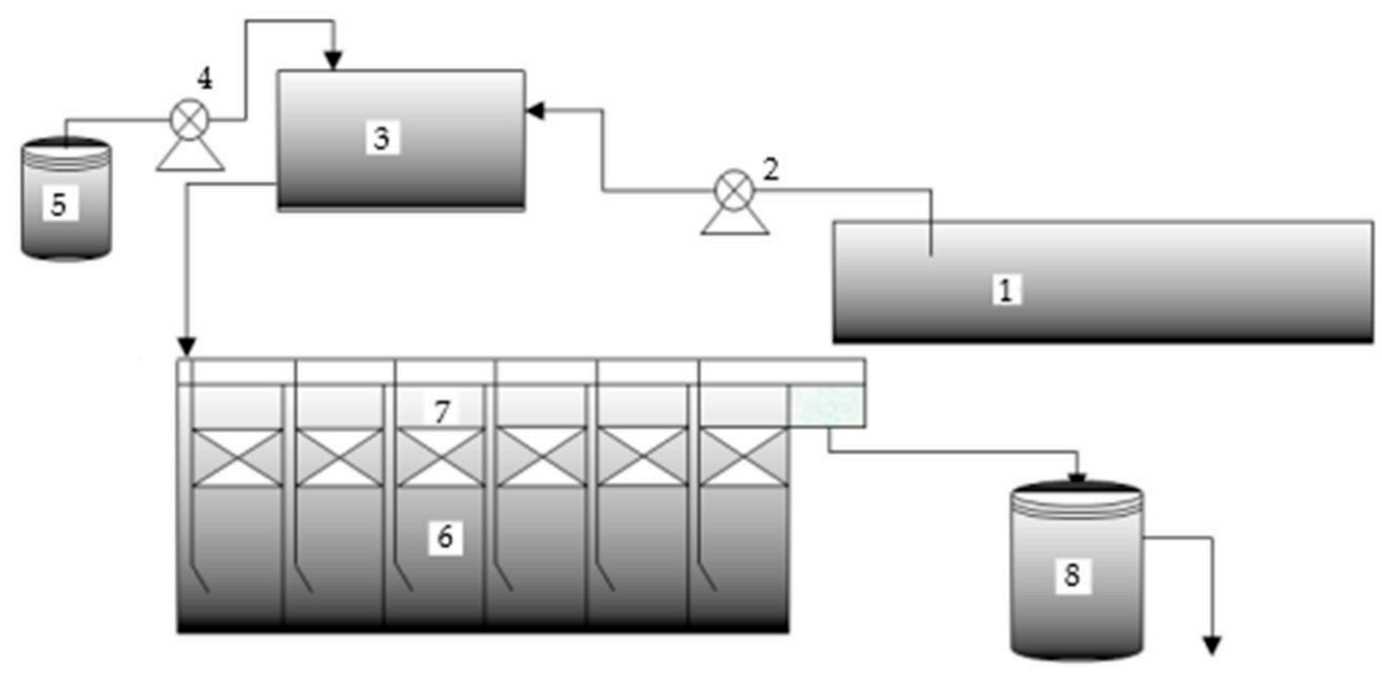

Figure 1. Flow chart of the hybrid anaerobic baffled reactor (HABR) reaction system. 1. coagulation sedimentation tank; 2. measuring pump; 3. inflow tank; 4. acid pump; 5 . acid tank; 6. hybrid anaerobic baffled reactor; 7 . cross-flow packing; 8 . catchment tank.

Influent wastewater was pumped from the coagulation pretreatment sedimentation tank to the inflow tank. $\mathrm{H}_{2} \mathrm{SO}_{4}$ was added by an acid pump to the inflow tank to regulate the influent $\mathrm{pH}$, and then wastewater flowed to the HABR by gravity. Temperature and $\mathrm{pH}$ were continuously monitored by on-line equipment. The outflow was collected by a catchment tank before the following aerobic treatment. 


\subsection{Start-up and Operation Scheme}

The sludge was inoculated from the sludge storage tank after concentration tank in a wastewater treatment plant. After deposition for a week, the supernatant was removed from the sludge. The inoculated sludge was evenly mixed, and then placed to the bottom of the HABR. The inoculated sludge occupied about $1 / 3$ volume in each compartment. The start-up condition was: hydraulic retention time (HRT) $60 \mathrm{~h}$, volatile suspended solid (VSS) 20-35 g/L, influent organic loading rate (OLR) $0.02-0.03 \mathrm{~kg} \mathrm{COD} /\left(\mathrm{m}^{3} \cdot \mathrm{d}\right.$ ), influent $\mathrm{pH} 7.0$, water temperature $15^{\circ} \mathrm{C}$ (in April). HRT is a key factor to affect the extent of fluid mixing and the treatment performance of the reactor. In this study, HRT was gradually reduced with the influent water quality fixed, which was beneficial to the sludge retention and thus the stability of the reactor operation. After the HABR was started at HRT of $60 \mathrm{~h}$, the flow rate was continuously increased by regulating the valve until the HRT reached designed retention time $12 \mathrm{~h}$ during the first 72 days. On average, HRT was decreased by $2 \mathrm{~h}$ every 3 days. During 73-131 days, HRT was maintained at $12 \mathrm{~h}$. Under influent OLR of $1.6-2.4 \mathrm{~kg} \mathrm{COD} /\left(\mathrm{m}^{3} \cdot \mathrm{d}\right)$, the COD removal effect of HABR was investigated. The $\mathrm{pH}$ was controlled below 9.0.

\subsection{Analytical Methods}

\subsubsection{Typical Water Quality Analysis}

In this study, water quality indexes including water temperature, $\mathrm{pH}, \mathrm{COD}, \mathrm{SS}, \mathrm{OLR}$, and alkalinity were analyzed at a certain period by standard methods [30]. Volatile fatty acid (VFA) was measured by gas chromatography [31].

\subsubsection{Gas Chromatography-Mass Spectrometry (GC-MS) Analysis}

Two methods were used to pretreat wastewater samples: (1) solid phase extraction (SPE). $100 \mathrm{~mL}$ sample was extracted directly, and another $100 \mathrm{~mL}$ sample was extracted after its $\mathrm{pH}$ was regulated by $\mathrm{H}_{2} \mathrm{SO}_{4}$ to 2 . The two portions of extracted liquor were mixed together, then washed by $5 \mathrm{~mL}$ acetacetic ester and $5 \mathrm{~mL}$ dichloromethane, and then concentrated to $1 \mathrm{~mL}$ by nitrogen insufflation. (2) liquid-liquid extraction (LLE). $200 \mathrm{~mL}$ sample was extracted by $100 \mathrm{~mL}$ dichloromethane, and then extracted by $100 \mathrm{~mL}$ dichloromethane again after its $\mathrm{pH}$ was regulated to 2 . The two portions of extracted liquor were mixed together, and then concentrated to $1 \mathrm{~mL}$ by revolving nitrogen insufflation.

Organic constituents of the wastewater samples were extracted by an Agilent 6890N GC and then qualitatively analyzed by an Agilent 5973N MSD (Mass Spectrometer Detector). A DB-5ms capillary column with length of $30 \mathrm{~m}$, nominal diameter of $0.25 \mathrm{~mm}$, and nominal film thickness of $0.25 \mu \mathrm{m}$ was used.

The chromatogram conditions were: the temperature for the sample inlet was $280{ }^{\circ} \mathrm{C}$; the temperature control program registered initial $45^{\circ} \mathrm{C}$, retaining for $3 \mathrm{~min}$, then increasing to $200^{\circ} \mathrm{C}$ with an increment rate of $10^{\circ} \mathrm{C} / \mathrm{min}$, then increasing to $310^{\circ} \mathrm{C}$ with an increment rate of $25^{\circ} \mathrm{C} / \mathrm{min}$, and then maintaining $310^{\circ} \mathrm{C}$ for $10 \mathrm{~min}$. The carrier gas was helium; flow rate was $1 \mathrm{~mL} / \mathrm{min}$ and front inlet was splitless. EI source (electron impact ion source) was used for MSD and its scan range was 15-750 amu. Compounds were identified from their molecular fragmentation and quantified from the peak area of their major fragment ions, according to the instrument library (NIST 05a) database.

\subsubsection{Generalized Grey Relational Analysis (GGRA)}

Generalized Grey Relational Analysis (GGRA) is an important constituent of grey system theory, which estimates the relational degree among different trends in grey process development based on the geometrically analogical degree among their corresponding time sequence curves. GGRA is a 
quantitative method of relational degree analysis in grey system among relevant factors, which uses grey relational grade to indicate the relational degree between system characteristic sequence and its relevant influencing sequence, in order to provide quantitative foundation to determine major factors in event development and transformation [32-34].

The generalized grey relational grade is defined by the authors as follows:

Set system characteristic sequence $X_{0}=\left(x_{0}(1), x_{0}(2), \cdots, x_{0}(n)\right)$, and its relevant influencing sequence $X_{i}=\left(x_{i}(1), x_{i}(2), \cdots, x_{i}(n)\right), i=1,2, \cdots, m$, let $X_{0}$ and $X_{i}$ divided by their sequence average respectively, we obtain $\overline{X_{0}}=\left(\overline{x_{0}(1)}, \overline{x_{0}(2)}, \cdots, \overline{x_{0}(n)}\right)=\left(\frac{x_{0}(1)}{\sum_{j=1}^{n} x_{0}(j) / n}, \frac{x_{0}(2)}{\sum_{j=1}^{n} x_{0}(j) / n}, \cdots, \frac{x_{0}(n)}{\sum_{j=1}^{n} x_{0}(j) / n}\right)$ and $\overline{X_{i}}=\left(\overline{x_{i}(1)}, \overline{x_{i}(2)}, \cdots, \overline{x_{i}(n)}\right)=\left(\frac{x_{i}(1)}{\sum_{j=1}^{n} x_{i}(j) / n}, \frac{x_{i}(2)}{\sum_{j=1}^{n} x_{i}(j) / n}, \cdots, \frac{x_{i}(n)}{\sum_{j=1}^{n} x_{i}(j) / n}\right), i=1,2, \cdots, m$, then let $X_{0}$ and $X_{i}$ subtract their first number, we obtain ${\overline{X_{0}}}^{0}=\left({\overline{x_{0}(1)}}^{0},{\overline{x_{0}(2)}}^{0}, \ldots,{\overline{x_{0}(n)}}^{0}\right)=$ $\left(\overline{x_{0}(1)}-\overline{x_{0}(1)}, \overline{x_{0}(2)}-\overline{x_{0}(1)}, \cdots, \overline{x_{0}(n)}-\overline{x_{0}(1)}\right) \quad$ and $\quad \bar{X}_{i}^{0}=\left({\overline{x_{i}(1)}}^{0},{\overline{x_{i}(2)}}^{0}, \ldots,{\overline{x_{i}(n)}}^{0}\right)=$ $\left(\overline{x_{i}(1)}-\overline{x_{i}(1)}, \overline{x_{i}(2)}-\overline{x_{i}(1)}, \cdots, \overline{x_{i}(n)}-\overline{x_{i}(1)}\right), i=1,2, \cdots, m$, and then the generalized grey relational grade is

$$
\gamma_{0 i}=\frac{1+\left|s_{0}\right|+\left|s_{i}\right|-\left|s_{i}-s_{0}\right|}{1+\left|s_{0}\right|+\left|s_{i}\right|+\left|s_{i}-s_{0}\right|}
$$

where $\left|s_{0}\right|=\left|\sum_{k=2}^{n-1}{\overline{x_{0}(k)}}^{0}+\frac{1}{2}{\overline{x_{0}(n)}}^{0}\right|,\left|s_{i}\right|=\left|\sum_{k=2}^{n-1}{\overline{x_{i}(k)}}^{0}+\frac{1}{2}{\overline{x_{i}(n)}}^{0}\right|$ and $\left|s_{i}-s_{0}\right|=\left|\sum_{k=2}^{n-1}\left({\overline{x_{i}(k)}}^{0}-{\overline{x_{0}(k)}}^{0}\right)+\frac{1}{2}\left({\overline{x_{i}(n)}}^{0}-{\overline{x_{0}(n)}}^{0}\right)\right|$.

In this study, the COD removal efficiency of dyeing wastewater by HABR was set as system characteristic sequence, and water temperature, flow rate, OLR, influent COD, influent $\mathrm{pH}$, influent SS, influent VFA, and influent alkalinity were relevant sequences, respectively. GGRA was used to perform system analysis to calculate the grey relational grades of influencing factors on COD removal effect.

\section{Results and Discussion}

\subsection{Performance of the Pilot Scale HABR}

\subsubsection{COD Removal}

The COD removal of this pilot scale HABR during operational period of 131 days is shown in Figure 2. Although the influent COD fluctuated in the approximate range of 700-1300 mg/L, HABR revealed good COD degradation performance. During the first 72 days, HABR was started up and COD removal rate continuously increased; during 73-131 $\mathrm{d}$, the average COD removal efficiency reached $33.7 \%$ at HRT of $12 \mathrm{~h}$. The efficiency could not reach very high, because some dye molecules in the wastewater were difficult to be degraded by anaerobic microbes. It can be seen from Table 1 that the COD removal rate in the pilot-scale anaerobic reactors is largely related to the OLR and the influent COD. Generally, the COD removal rate can reach over $40 \%$ when the OLR and influent COD are roughly less than $1.8 \mathrm{~kg} \mathrm{COD} /\left(\mathrm{m}^{3} \cdot \mathrm{d}\right)$ and $1000 \mathrm{mg} / \mathrm{L}$, respectively. Under similar conditions, the COD removal rates in the pilot scale reactors are normally lower than that of the laboratory scale reactors, mainly because the "dead zone" in the former is larger so that the fluids inside can hardly mix very well. The COD removal performance in this $18 \mathrm{~m}^{3}$ reactor was significantly better than that of the $5 \mathrm{~m}^{3}$ UASB reactor under similar conditions [9]. This indicated that the compartmented configuration was favorable for the degradation of COD by the anaerobic microbes growing in separated rooms. 


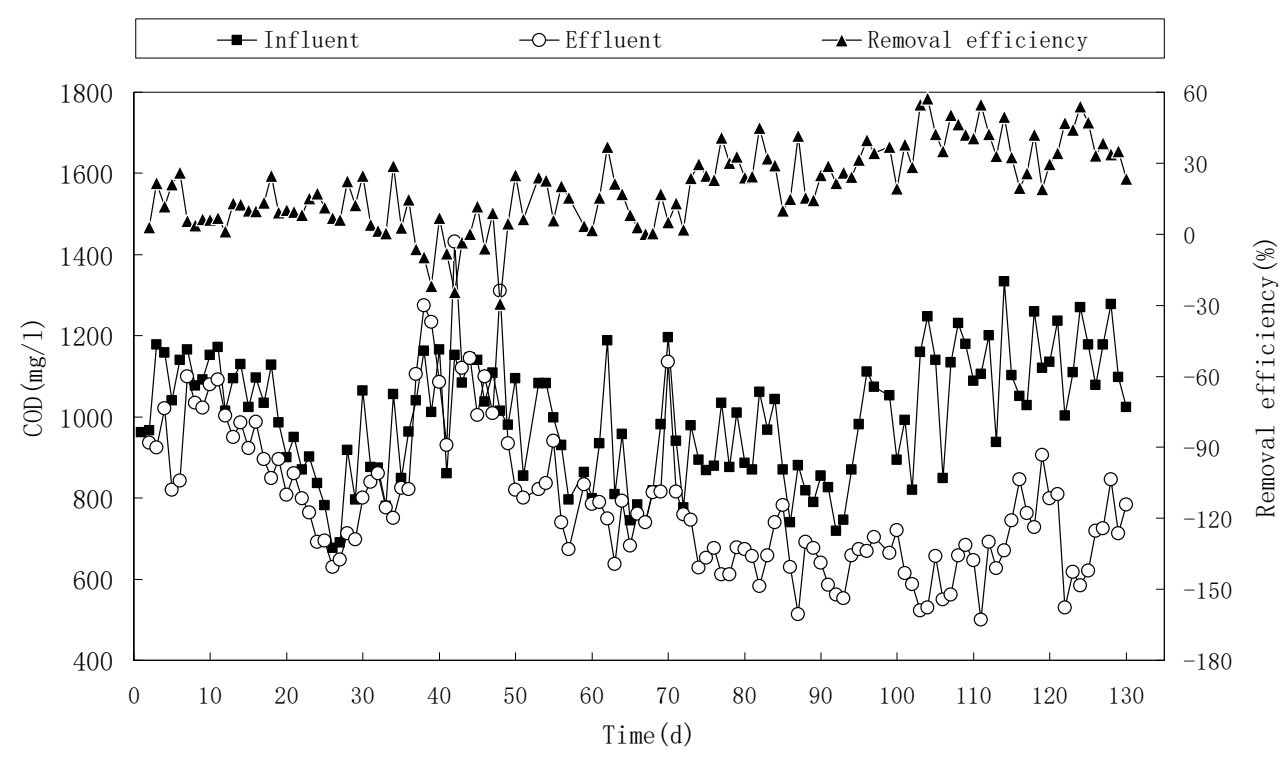

Figure 2. Chemical oxygen demand (COD) removal during the 131 days operation of hybrid anaerobic baffled reactor (HABR).

\subsubsection{Sulfates Removal}

Sulfates in the organic wastewater can be reduced by sulfate-reducing bacteria (SRB) to $\mathrm{S}^{2-}, \mathrm{HS}^{-}$, and $\mathrm{H}_{2} \mathrm{~S}$. Sulfates degradation of the HABR during operational period of 37-131 days is shown in Figure 3. In this study, the sulfates concentrations in the influent were in the relatively high range of around 800 to $1200 \mathrm{mg} / \mathrm{L}$. During the start-up period, sulfates removal efficiency by HABR was over 33\%, which accounted for a good performance of sulfate-reducing bacteria. After $72 \mathrm{~d}$, the sulfates removal efficiency declined to $22.5 \%$ in average, which indicated that the activity of sulfate-reducing bacteria was gradually inhibited by acid-producing bacteria and methanogens as well as the accumulation of the product $\mathrm{S}^{2-}$. In a previous study conducted in an ABR reactor with COD to sulfates mass concentration ratio $1.0-1.5$, the sulfates reduction rate achieved over $60 \%$ and the $\mathrm{S}^{2-}$ concentration reached $100-120 \mathrm{mg} / \mathrm{L}$ [13]. In that test, to weaken the inhibition of $\mathrm{S}^{2-}$ on anaerobic microbes, $\mathrm{Fe}^{2+}$ had to be added, and the formed FeS was removed by the subsequent coagulation-sedimentation process. The reduction of $\mathrm{S}^{2-}$ would be favorable for the growth of methanogens [35].

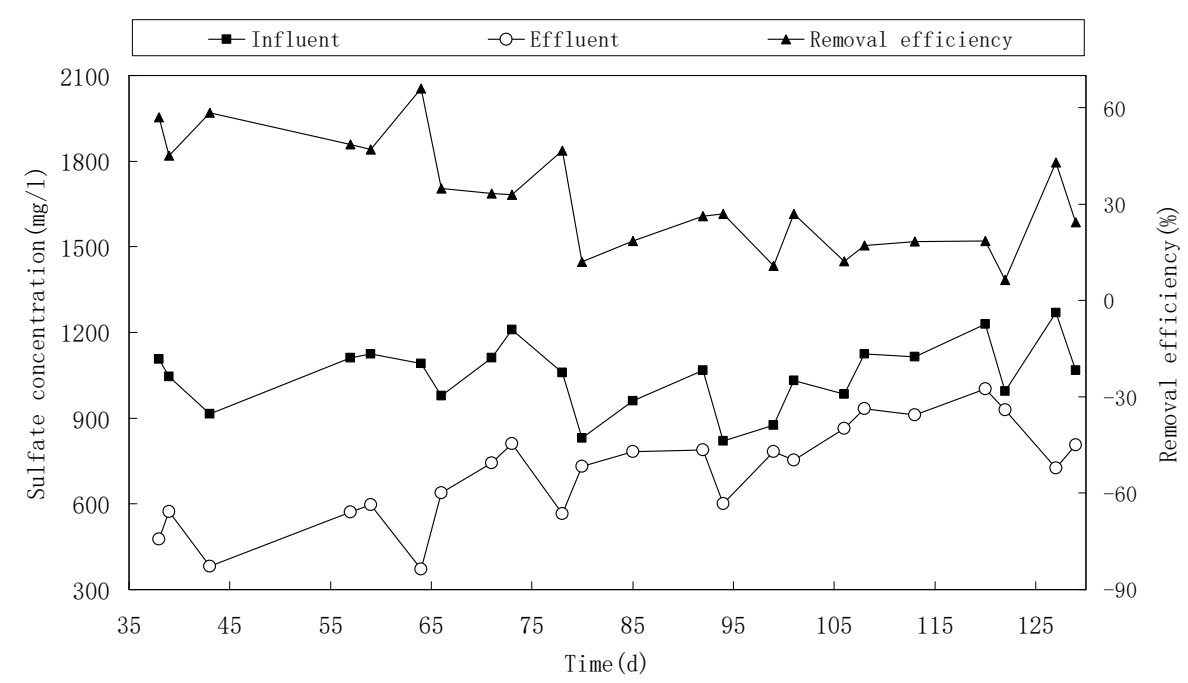

Figure 3. Sulfates removal of the hybrid anaerobic baffled reactor (HABR) during operational period of 37-131 days. 


\subsubsection{SS Removal}

SS removal effect of HABR during operational period of 56-131 days is shown in Figure 4. The variation range of SS in the influent was wide around $100-700 \mathrm{mg} / \mathrm{L}$; in contrast, that in the effluent was limited to around $50-350 \mathrm{mg} / \mathrm{L}$, which was beneficial for the steady operation of the subsequent system. During the operational period of 55-131 d, the average SS removal efficiency in the HABR system was $39.9 \%$. Although SS reduction is not the main purpose of anaerobic treatment, it can decrease a portion of toxic substances possibly existing in the suspended matter.

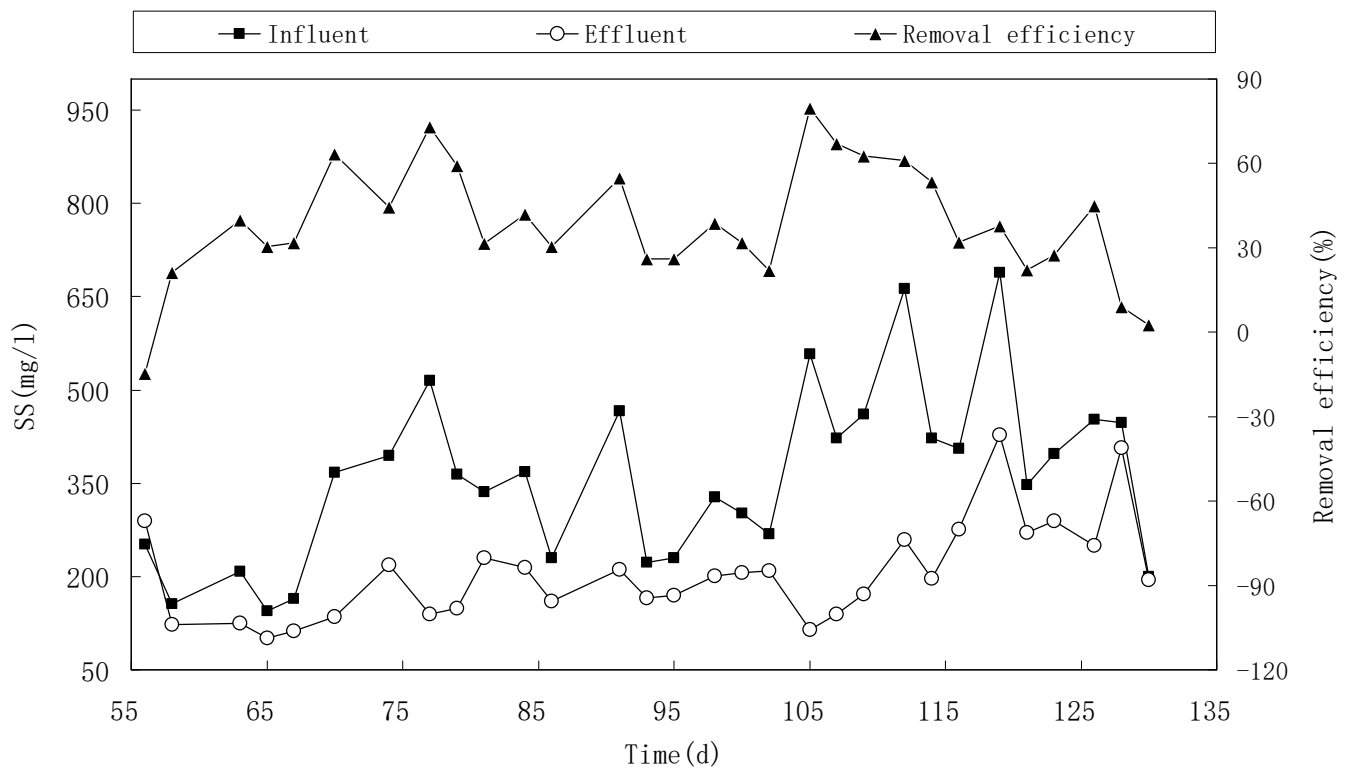

Figure 4. Suspended solid (SS) removal of the hybrid anaerobic baffled reactor (HABR) during operational period of 56-131 days.

\subsection{Organic Compounds Degradation by Hybrid Anaerobic Baffled Reactor (HABR)}

The degradability of wastewater is remarkably affected by the type of organic compounds in it [36]. In order to further investigate the removal of different organic compounds and their biodegradability in different process units, GC-MS analysis was performed. The organic compound type numbers in the HABR influent and effluent are shown in Figure 5. GC-RMS analysis was performed to qualitatively characterize the pollutant types in the influent and effluent of the HABR. The results demonstrated that the quality of the influent was extremely complex, in terms of a large number of alkanes, amides, organic acids, ketones, phenols, and esters. Although COD was not decreased heavily through the HABR system, the number of organic compound types in the effluent was decreased to 44 , while that in the influent was 84 . The chemical structure of several compounds generally displayed substantial variation through the HABR system. Especially, the decrease of alkane types and increase of alkene types indicated that a number of long-chain alkanes were divided to alkenes under anaerobic condition. The HABR performed better in reducing the categories of alkanes than an EGSB reactor that decreased alkanes to 17 types [12]. Following the treatment, many high-molecular-weight compounds, such as cyclanes, quinolines, and phenols, were also converted to low-molecular-weight ones, which became much easier to be degraded further through subsequent aerobic techniques. The results indicated that HABR showed good performance on degrading some structurally complex and biologically refractory substances, which indicated the improvement of biodegradability of the wastewater [16]. 


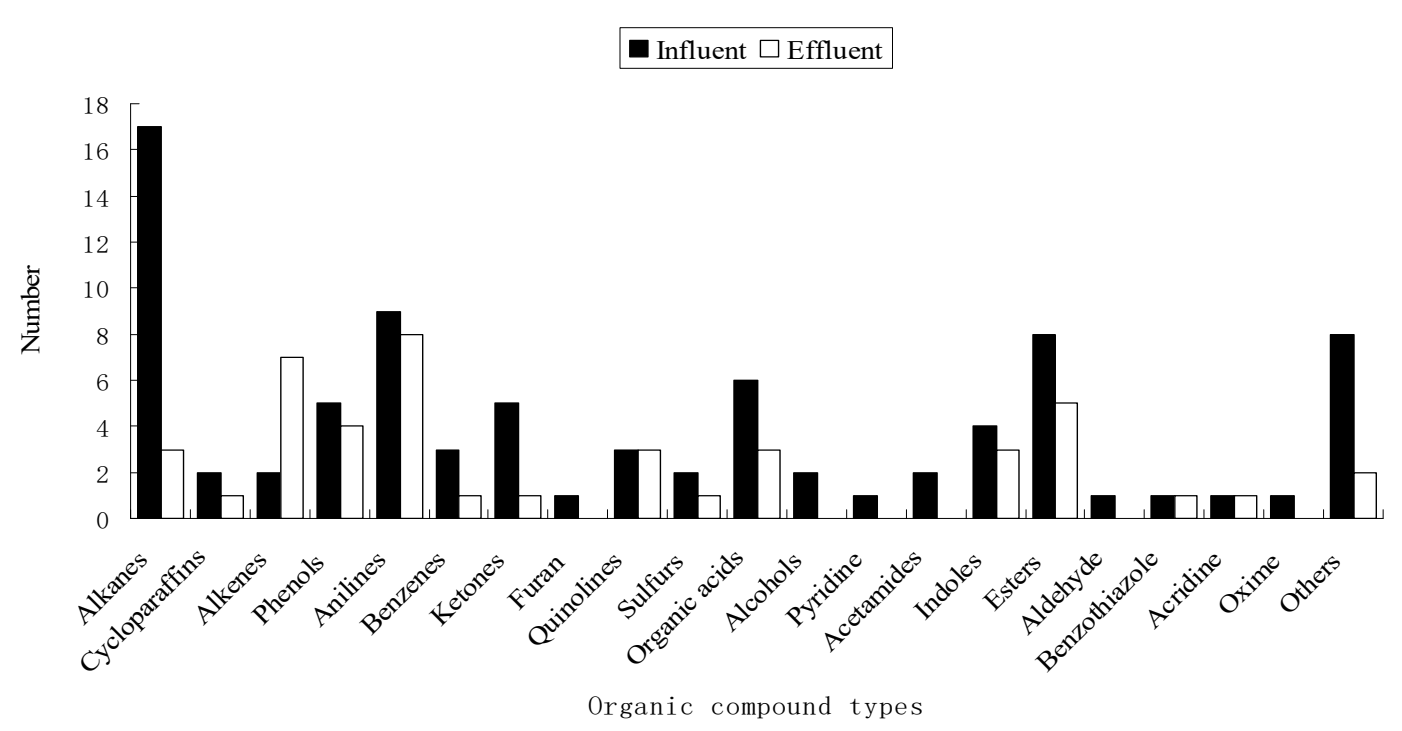

Figure 5. Numbers of the organic compound type in the hybrid anaerobic baffled reactor (HABR) influent and effluent.

\subsection{Relevant Factors for Chemical Oxygen Demand (COD) Removal Effect}

\subsubsection{Calculation Results of Generalized Grey Relational Grade}

Table 3 shows the generalized grey relational grade of relevant influencing factors on COD removal effect. The results showed that flow rate, OLR, influent SS, and water temperature revealed strong correlation with COD removal effect.

Table 3. Generalized Grey Relational Grade of Respective Factors on Chemical Oxygen Demand (COD) Removal Effectiveness.

\begin{tabular}{ccccc}
\hline Influencing Factor & Temperature & Flow Rate & $\begin{array}{c}\text { Organic Loading } \\
\text { Rate (OLR) }\end{array}$ & $\begin{array}{c}\text { Influent Chemical } \\
\text { Oxygen Demand (COD) }\end{array}$ \\
\hline $\begin{array}{c}\text { Generalized grey } \\
\text { relational grade }\end{array}$ & 0.58 & 0.94 & 0.87 & 0.02 \\
\hline Influencing factor & Influent pH & Influent SS & Influent VFA & Influent alkalinity \\
\hline $\begin{array}{c}\text { Generalized grey } \\
\text { relational grade }\end{array}$ & 0.14 & 0.63 & 0.14 & 0.13 \\
\hline
\end{tabular}

\subsubsection{Correlation between Chemical Oxygen Demand (COD) Removal Efficiency and Flow Rate}

It has been found that too low a flow rate would reduce the mixture degree between the sludge and wastewater, but too high a flow might render the bacteria unable to degrade the substrates effectively [15]. In this study, the variation of COD removal efficiency and the influent flow rate with time is shown in Figure 6a. It can be seen that the COD removal efficiency increased with the increase of flow rate in most of the days. However, it is worthy to note that the COD removal rate was very low at day 31 and day 68, probably caused by the sudden rise of flow rate and toxicity of the suspended solids in the influent. The value of flow rate could directly influence the anaerobic treatment effect on dyeing wastewater. The smaller the flow rate was, the longer the HRT was, which would ensure that HABR had sufficient time to effectively degrade the pollutants in the wastewater [13]. However, in real project, the flow rate should be controlled as large as possible, which might reduce the land area of the reactor so as to diminish the construction and operation investment. 


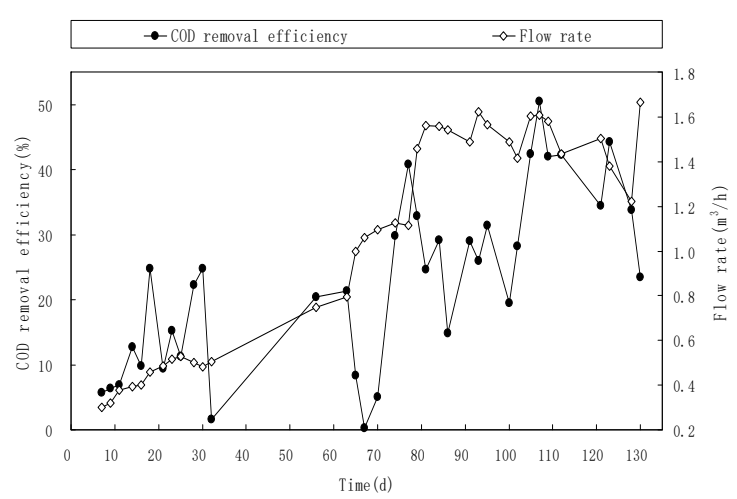

(a)

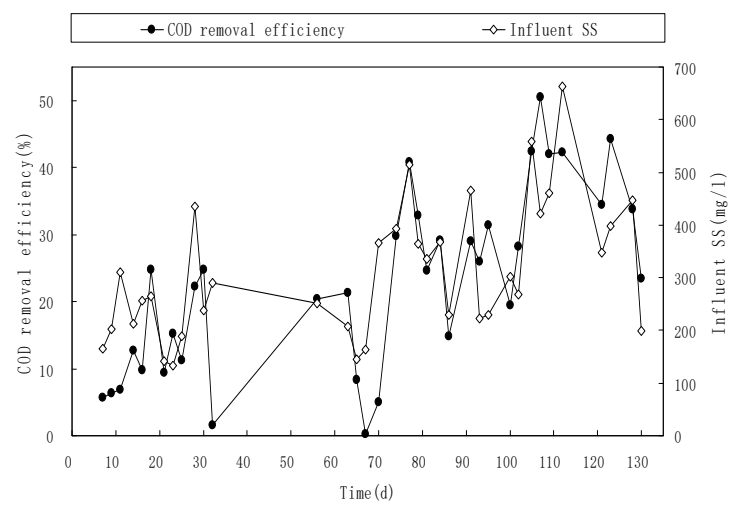

(c)

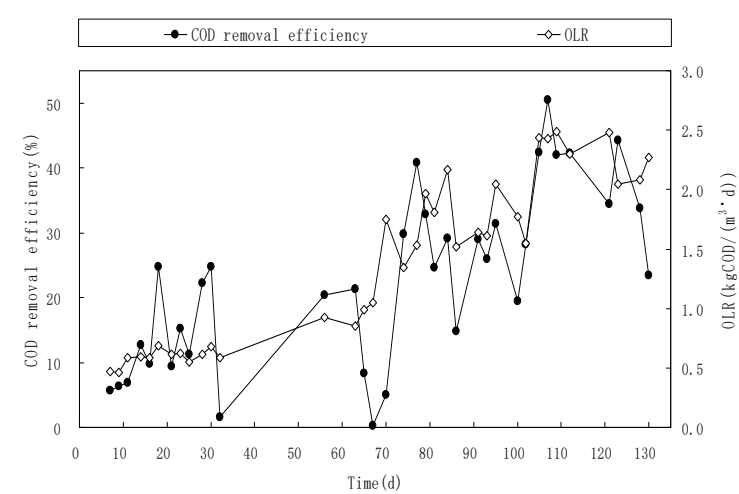

(b)

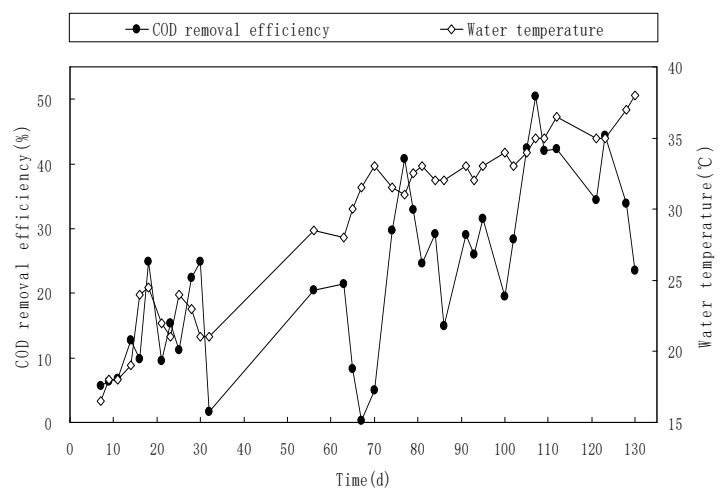

(d)

Figure 6. Time series of chemical oxygen demand (COD) removal efficiency with (a) flow rate; (b) organic loading rate (OLR); (c) influent suspended solid (SS); (d) water temperature.

During the operational period of 73-107 days, activated microorganisms performed evident functions of hydrolyzing and acidifying dyeing wastewater, when the flow rate was $1.5 \mathrm{~m}^{3} / \mathrm{h}$, the corresponding up-flow rate was $1.7 \mathrm{~m} / \mathrm{h}$, and the HRT was $12 \mathrm{~h}$. Compared with the optimal parameters obtained by other studies employing anaerobic technologies for dyeing wastewater treatment (Table 1), this HABR realized a relatively low HRT and thus a high up-flow velocity, mainly due to the effect of the cross-flow packing on stabilizing the microbes and enhancing the contact between the sludge and wastewater [16].

\subsubsection{Correlation between Chemical Oxygen Demand (COD) Removal Efficiency and Organic} Loading Rate (OLR)

OLR performed strong correlation with the COD removal effect, shown in Figure 6b. In general, too low OLR is not beneficial for the proliferation of various microbial communities in the inoculated sludge; because of the stronger adaptability and fecundity of acid-producing bacteria, too high or too fluctuant OLR might lead to systemic acidification and excessive proliferation of acid-producing bacteria, which would further result in the maladjusted proportion of bacterial communities and ruinate stabilization of granule sludge [37]. During the start-up period, the COD removal efficiency increased with the increase of OLR, which indicated that the OLR was controlled in a proper range so that the activity of anaerobic microbes was continuously promoted to degrade organic matter. During 73-107 days, the variation range of OLR was $1.5-2.0 \mathrm{~kg} \mathrm{COD} /\left(\mathrm{m}^{3} \cdot \mathrm{d}\right)$. Compared with other studies which achieved a similar COD removal efficiency (Table 1), the OLR range in this $18 \mathrm{~m}^{3}$ reactor was 
close to that of the EGSB and UASB with an effective working volume of $0.78 \mathrm{~m}^{3}$, which further validated the scale-up of this configuration.

\subsubsection{Correlation between Chemical Oxygen Demand (COD) Removal Efficiency and Influent SS}

Influent SS revealed positive correlation with COD removal efficiency, shown in Figure 6c. The relationship between the COD removal and the influent SS has not yet been clearly revealed by other reported researches. The higher the influent suspended solid concentration was, the higher the COD removal efficiency was, because the anaerobic sludge and the cross-flow packing layers intercepted a portion of insoluble compounds which contributed to the total COD value in suspended solids. However, SS might be accumulated in the anaerobic reactor so that the anaerobic sludge activity would fall down. Therefore, in order to maintain sludge activity, it is indispensable to discharge an appropriate amount of sludge in HABR at a certain term.

\subsubsection{Correlation between Chemical Oxygen Demand (COD) Removal Efficiency and Water Temperature}

Water temperature is an important environmental factor in anaerobic treatment process, which influences COD removal efficiency to a great extent, shown in Figure 6d. Water temperature impacts hydrolyzation and acidification based on general biological law, where the higher the temperature is, the faster the reacting rate in a certain range will be. At temperature lower than $5{ }^{\circ} \mathrm{C}$, the activity of anaerobic sludge will be decreased, which may result in the deterioration of the biochemical reaction and hydrolysis process. An ABR was used to treat textile dyeing wastewater and it was found that raising wastewater temperature could help to increase COD removal efficiency [38]. During the 73-107 days of this test, the water temperature range was $30-35^{\circ} \mathrm{C}$, which realized satisfactory biological degradation by the reactor.

\section{Conclusions}

The HABR for treating dyeing wastewater was systematically investigated in this pilot scale study. The HABR system was able to treat the wastewater efficiently after $\mathrm{FeSO}_{4}$ pretreatment, as indicated by removal efficiencies of $33.7 \%$ for COD and $39.9 \%$ for SS, as well as $22.5 \%$ for $\mathrm{SO}_{4}{ }^{2-}$ during operational period of 73-107 days. HABR may maintain a relatively high COD removal efficiency at high concentrations of sulfates (approximately $800-1200 \mathrm{mg} / \mathrm{L}$ ) and SS (maximumly between $500-700 \mathrm{mg} / \mathrm{L}$ ) and large fluctuation of SS concentrations (around 100-700 mg/L) in the influent. Results of GC-MS analysis indicated a satisfactory biodegradability improvement of the wastewater: the concentrations of alkanes, amides, organic acids, ketones, phenols, and esters were much lower in the effluent than those in the influent; many high-molecular-weight compounds such as cyclanes, quinolines, and phenols were successfully converted to low-molecular-weight ones. COD removal efficiency was closely associated with flow rate, OLR, water temperature, and influent SS.

Based on the overall treating effectiveness and the GGRA study, the optimized operation strategy of HABR to process the dyeing wastewater was obtained as the HRT of $12 \mathrm{~h}$ for steady-state operation, up-flow velocity of $1.7 \mathrm{~m} / \mathrm{h}$, water temperature of $30-35^{\circ} \mathrm{C}$, and OLR of $1.5-2.0 \mathrm{~kg} \mathrm{COD} /\left(\mathrm{m}^{3} \cdot \mathrm{d}\right)$.

For the next stage, water indexes and dominant microbes in each compartment will be investigated to prove the separation of microbial populations by the ABR technique. Meanwhile, the biodegradability of the effluent to the subsequent aerobic treatment unit will be further validated. In addition, the results obtained from this work will be confirmed by testing the performance of full-scale plants $[39,40]$.

Author Contributions: Conceptualization, Methodology, Formal analysis, Funding acquisition, Writing-original draft, Z.Q.; Investigation, Software, G.X.; Writing-review and editing, D.X.

Funding: This research was funded by National Natural Science Foundation of China (41807466), the Fundamental Research Funds for the Central Universities (3132019148), and the Natural Science Foundation of Liaoning Province, China (20170540099). 
Acknowledgments: Zhaobo Chen, Wanqian Guo and Shijie You are thanked for their comments on this work.

Conflicts of Interest: The authors declare no conflict of interest.

\section{References}

1. Yao, L.; Zhang, L.; Wang, R.; Chou, S.; Dong, Z.L. A new integrated approach for dye removal from wastewater by polyoxometalates functionalized membranes. J. Hazard. Mater. 2016, 301, 462-470. [CrossRef]

2. Zonoozi, M.H.; Moghaddam, M.R.A.; Maknoon, R. Operation of integrated sequencing batch membrane bioreactor treating dye-containing wastewater at different SRTs: Study of overall performance and fouling behavior. Environ. Sci. Pollut. Res. 2015, 22, 5931-5942. [CrossRef] [PubMed]

3. Yaseen, D.A.; Scholz, M. Shallow pond systems planted with Lemna minor treating azo dyes. Ecol. Eng. 2016, 94, 295-305. [CrossRef]

4. Yaseen, D.A.; Scholz, M. Textile dye wastewater characteristics and constituents of synthetic efuents: A critical review. Int. J. Environ. Sci. Technol. 2019, 16, 1193-1226. [CrossRef]

5. Dafale, N.; Wate, S.; Meshram, S.; Neti, N.R. Bioremediation of wastewater containing azo dyes through sequential anaerobic-aerobic bioreactor system and its biodiversity. Environ. Rev. 2010, 18, 21-36.

6. Hakimelahi, M.; Moghaddam, M.R.A.; Hashemi, S.H. Biological treatment of wastewater containing an azo dye using mixed culture in alternating anaerobic/aerobic sequencing batch reactors. Biotechnol. Bioproc. Eng. 2012, 17, 875-880. [CrossRef]

7. Wang, Y.M.; Cao, W.P.; Jiang, J.L.; Chen, J. Performance of an anaerobic baffled reactor (ABR) for the pretreatment of dyeing industry wastewater. Desalin. Water Treat. 2017, 68, 338-344.

8. Wang, J.; Long, M.C.; Zhang, Z.J.; Chi, L.N.; Qiao, X.L.; Zhu, H.X.; Zhang, Z.F. Removal of organic compounds during treating printing and dyeing wastewater of different process units. Chemosphere 2008, 71, 195-202. [CrossRef] [PubMed]

9. Li, Y.; Zhang, J.X.; Zhang, Y.B.; Quan, X. Scaling-up of a zero valent iron packed anaerobic reactor for textile dye wastewater treatment: A potential technology for on-site upgrading and rebuilding of traditional anaerobic wastewater treatment plant. Water Sci. Technol. 2017, 76, 823-831. [CrossRef]

10. Haider, A.; Khan, S.J.; Nawaz, M.S. Effect of intermittent operation of lab-scale upflow anaerobic sludge blanket (UASB) reactor on textile wastewater treatment. Desalin. Water Treat. 2018, 136, 120-130. [CrossRef]

11. Zhang, Y.B.; Liu, Y.W.; Jing, Y.W.; Zhao, Z.Q.; Quan, X. Steady performance of a zero valent iron packed anaerobic reactor for azo dye wastewater treatment under variable influent quality. J. Environ. Sci. 2012, 24, 720-727. [CrossRef]

12. Wang, J.; Zhang, Z.J.; Chi, L.N.; Qiao, X.L.; Zhu, H.X.; Long, M.C.; Zhang, Z.F. Performance of anaerobic process on toxicity reduction during treating printing and dyeing wastewater. Bull. Environ. Contam. Toxicol. 2007, 78, 531-534. [CrossRef]

13. Huang, R.M.; Liu, Z.; Zhou, X.J.; Mo, J.C.; Liu, X. Research on treatment of printing and dyeing wastewater by hybrid anaerobic baffled reactor. Desalin. Water Treat. 2015, 54, 590-597. [CrossRef]

14. Yang, Y.G.; Luo, O.; Kong, G.N.; Wang, B.; Li, X.J.; Li, E.; Li, J.J.; Liu, F.F.; Xu, M.Y. Deciphering the anode-enhanced azo dye degradation in anaerobic baffled reactors integrating with microbial fuel cells. Front. Microbiol. 2018, 9, 2117. [CrossRef]

15. Yang, B.; Xu, H.; Yang, S.N.; Bi, S.T.; Li, F.; Shen, C.S.; Ma, C.Y.; Tian, Q.; Liu, J.S.; Song, X.S.; et al. Treatment of industrial dyeing wastewater with a pilot-scale strengthened circulation anaerobic reactor. Bioresour. Technol. 2018, 264, 154-162. [CrossRef]

16. Xu, H.; Yang, B.; Liu, Y.B.; Li, F.; Shen, C.S.; Ma, C.Y.; Tian, Q.; Song, X.S.; Sand, W. Recent advances in anaerobic biological processes for textile printing and dyeing wastewater treatment: A mini-review. World J. Microbiol. Biotechnol. 2018, 34, 1-9. [CrossRef]

17. Rajasimman, M.; Babu, S.V.; Rajamohan, N. Biodegradation of textile dyeing industry wastewater using modified anaerobic sequential batch reactor-Start-up, parameter optimization and performance analysis. J. Taiwan Inst. Chem. Eng. 2017, 72, 171-181. [CrossRef]

18. Cheng, C.; Zhou, Z.; Qiu, Z.; Yang, J.Y.; Wu, W.; Pang, H.J. Enhancement of sludge reduction by ultrasonic pretreatment and packing carriers in the anaerobic side-stream reactor: Performance, sludge characteristics and microbial community structure. Bioresour. Technol. 2018, 249, 298-306. [CrossRef] 
19. Wang, T.; Wang, X.; Yuan, L.; Luo, Z.; Indira, K.H. Start-up and operational performance of Anammox process in an anaerobic baffled biofilm reactor (ABBR) at a moderate temperature. Bioresour. Technol. 2019, 279, 1-9. [CrossRef]

20. Gulhane, M.; Pandit, P.; Khardenavis, A.; Singh, D.; Purohit, H. Study of microbial community plasticity for anaerobic digestion of vegetable waste in Anaerobic Baffled Reactor. Renew. Energy 2017, 101, 59-66. [CrossRef]

21. Liu, R.; Lu, X.; Tian, Q.; Yang, B.; Chen, J. The performance evaluation of hybrid anaerobic baffled reactor for treatment of PVA-containing desizing wastewater. Desalination 2011, 271, 287-294.

22. Barber, W.P.; Stuckey, D.C. The use of the anaerobic baffled reactor (ABR) for wastewater treatment: A review. Water Res. 1999, 33, 1559-1578. [CrossRef]

23. Reynaud, N.; Buckley, C.A. The anaerobic baffled reactor (ABR) treating communal wastewater under mesophilic conditions: A review. Water Sci. Technol. 2016, 73, 463-478. [CrossRef]

24. Renuka, R.; Mohan, S.M.; Sowmiya, B.; Raj, S.A. Performance evaluation of panelled anaerobic baffle-cum-filter reactor in treating municipal wastewater. Ecol. Eng. 2016, 97, 1-12. [CrossRef]

25. Huang, L.H.; Sun, G.P.; Yang, T.; Zhang, B.; He, Y.; Wang, X.H. A preliminary study of anaerobic treatment coupled with micro-electrolysis for anthraquinone dye wastewater. Desalination 2013, 309, 91-96. [CrossRef]

26. Li, C.; Ren, H.Q.; Yin, E.; Tang, S.Y.; Li, Y.; Cao, J.S. Pilot-scale study on nitrogen and aromatic compounds removal in printing and dyeing wastewater by reinforced hydrolysis-denitrification coupling process and its microbial community analysis. Environ. Sci. Pollut. Res. 2015, 22, 9483-9493. [CrossRef]

27. Köchling, T.; Ferraz, A.D.N.; Florencio, L.; Kato, M.T.; Gavazza, S. 454-Pyrosequencing analysis of highly adapted azo dye-degrading microbial communities in a two-stage anaerobic-aerobic bioreactor treating textile effluent. Environ. Technol. 2016, 38, 687-693. [CrossRef] [PubMed]

28. Ji, J.; Liu, Y.; Yang, X.Y.; Xu, J.; Li, X.Y. Multiple response optimization for high efficiency energy saving treatment of rhodamine B wastewater in a three-dimensional electrochemical reactor. J. Environ. Manag. 2018, 218, 300-308. [CrossRef]

29. Wu, H.F.; Wang, S.H.; Kong, H.L.; Liu, T.T.; Xia, M.F. Performance of combined process of anoxic baffled reactor-biological contact oxidation treating printing and dyeing wastewater. Bioresour. Technol. 2007, 98, 1501-1504. [CrossRef]

30. Standard Methods for the Examination of Water and Wastewater, 20th ed.; American Public Health Association: Washington, DC, USA, 2005.

31. Wang, Y.Y.; Zhang, Y.L.; Wang, J.B.; Meng, L. Effects of volatile fatty acid concentrations on methane yield and methanogenic bacteria. Biomass Bioenergy 2009, 33, 848-853. [CrossRef]

32. Fang, F.; Jiang, H.; Wang, J.; Yu, H.Q. Identifying the influential priority of the factors governing PHB production by activated sludge with integration of uniform design and grey relational analysis. Seperation Purif. Technol. 2014, 136, 111-114. [CrossRef]

33. Guo, J.; Kang, Y. Characterization of sulfate-reducing bacteria anaerobic granular sludge and granulometric analysis with grey relation. Korean J. Chem. Eng. 2018, 35, 1829-1835. [CrossRef]

34. Zeng, G.M.; Jiang, R.; Huang, G.H.; Xu, M.; Li, J.B. Optimization of wastewater treatment alternative selection by hierarchy grey relational analysis. J. Environ. Manag. 2007, 82, 250-259. [CrossRef] [PubMed]

35. Zhang, W.J.; Liu, F.B.; Wang, D.Q.; Jin, Y. Impact of reactor configuration on treatment performance and microbial diversity in treating high-strength dyeing wastewater: Anaerobic flat-sheet ceramic membrane bioreactor versus upflow anaerobic sludge blanket reactor. Bioresour. Technol. 2018, 269, 269-275. [CrossRef] [PubMed]

36. Amaral, F.M.; Florêncio, L.; Kato, M.T.; Santa-Cruz, P.A.; Gavazza, S. Hydraulic retention time influence on azo dye and sulfate removal during the sequential anaerobic-aerobic treatment of real textile wastewater. Water Sci. Technol. 2017, 76, 3319-3327. [CrossRef] [PubMed]

37. Aris, M.A.M.; Chelliapan, S.; Din, M.F.D.; Anuar, A.N.; Shahperi, R.; Selvam, S.B.; Abdullah, N.; Yuzir, A. Effect of organic loading rate (OLR) on the performance of modified anaerobic baffled reactor (MABR) supported by slanted baffles. Desalin. Water Treat. 2017, 79, 56-63. [CrossRef]

38. Kong, H.L.; Wu, H.F. Pretreatment of textile dyeing wastewater using an anoxic baffled reactor. Bioresour. Technol. 2008, 99, 7886-7891. [CrossRef] 
39. Drewnowski, J.; Remiszewska-Skwarek, A.; Fudala-Ksiazek, S.; Luczkiewicz, A.; Kumari, S.; Bux, F. The evaluation of COD fractionation and modeling as a key factor for appropriate optimization and monitoring of modern cost-effective activated sludge systems. J. Environ. Sci. Health A 2018, 1-9. [CrossRef]

40. Drewnowski, J.; Makinia, J.; Kopec, L.; Fernandez-Morales, F.J. Modelization of nutrient removal processes at a large WWTP using a modified ASM2d model. Int. J. Environ. Res. Public Health. 2018, 15, 2817. [CrossRef]

(C) 2019 by the authors. Licensee MDPI, Basel, Switzerland. This article is an open access article distributed under the terms and conditions of the Creative Commons Attribution (CC BY) license (http://creativecommons.org/licenses/by/4.0/). 